\title{
Management of Islamic Religious Education In Developing The Noble Ability of Santries Through The Tahfidz Approach
}

\author{
Rohaeti, Ulfiah, Daeng Arifin, Ahmad Khori \\ Nusantara Islamic University, Bandung, Indonesia \\ Nusantara Islamic University, Bandung, Indonesia \\ Nusantara Islamic University, Bandung, Indonesia \\ Email: ummi.ribbiyan@yahoo.com, profulfiahwarek4@gmail.com, daengarifin@uninus.ac.id, \\ ahmadkhori84@gmail.com
}

\begin{tabular}{|c|c|}
\hline ARTICLE INFO & 3STRACT \\
\hline $\begin{array}{l}\text { Received } \\
23 \text { Juny } 2021 \\
\text { Revision } \\
1 \text { July } 2021 \\
\text { Approved } \\
10 \text { July } 2021 \\
\end{array}$ & $\begin{array}{l}\text { The purpose of national education in Law Number } 20 \text { of } 2003 \\
\text { concerning the National Education System chapter II article } 3 \\
\text { emphasizes the aspect of faith and devotion, the second aspect is } \\
\text { noble character. However, the practice of education in Indonesia is } \\
\text { still not in accordance with the functions and objectives of national } \\
\text { education. Pesantren is an appropriate model of education in fostering }\end{array}$ \\
\hline $\begin{array}{l}\text { Keywords: } \\
\text { PAI management } \\
\text { akhlaq noble } \\
\text { tahfidz }\end{array}$ & $\begin{array}{l}\text { noble character because students are fully trained and accustomed to } \\
\text { filling their sight, hearing and heart with content that is beneficial for } \\
\text { their lives. The tahfidz approach is the right approach in fostering } \\
\text { noble character because the series of processes in tahfidz activities are } \\
\text { able to bring students closer to the Qur'an and Allah. The problem of } \\
\text { students' morals is caused by several things including an inappropriate } \\
\text { approach, an atmosphere or culture that is not yet supportive, teacher } \\
\text { competence, and the lack of adequate human resources for tahfidz } \\
\text { teachers. The approach used in this study is a qualitative interactive } \\
\text { mode of inquiry approach. The method used is descriptive analytical } \\
\text { method with a variety of case studies. While the data collection } \\
\text { techniques are observation/observation, participation, interviews, and } \\
\text { literature study. The conclusion is that the Pesantren Leader and the } \\
\text { team that was formed made a context analysis document as a study in } \\
\text { planning. The planning of Islamic religious education in order to foster } \\
\text { noble character in the two Islamic boarding schools, namely the } \\
\text { Tahfidz Misbahunnur Islamic Boarding School in Cimahi City and the } \\
\text { Darul Arqom Muhammadiyah Islamic Boarding School in Garut } \\
\text { Regency, is stated in the pesantren curriculum document. The } \\
\text { implementation of Islamic religious education management is carried } \\
\text { out through the tahfidz approach. The two pesantren set a number of } \\
\text { indicators of the success of the Islamic religious education } \\
\text { management process in fostering noble character through the tahfidz } \\
\text { approach, namely: obedience to Allah and His Messenger, enthusiasm, } \\
\text { tolerance, carefulness, thoroughness, compassion, patience and } \\
\text { honesty. }\end{array}$ \\
\hline
\end{tabular}

How to cite:

E-ISSN:

Published by:
Rohaeti, Ulfiah, Daeng Arifin, Ahmad Khori (2021) Analysis of The Effect of Compensation, Organizational Commitment, and Work Environment on Employee Performance. Jurnal of Social Science 2(4). https://doi.org/10.46799/jss.v2i4.180 2721-5202

Ridwan Institute 


\section{INTRODUCTION}

The decline in the morality of the nation's children has begun to touch elementary school-aged children (SD), some are involved in drugs, acts of violence between friends, sexuality, and even murder. This issue will receive special attention from education experts, especially character education experts or noble character education, because it is an indication that the implementation of noble character education learning in schools has not met the expectations as stated in Law Number 20 of 2003 concerning the National Education System, namely develop capabilities and shape the character and civilization of a dignified nation. This in the long term has an impact on the destruction of cultural values and the nation's personality as well as the removal of noble character from social reality that has been developed by the nation's founders and has become Indonesia's identity as a religious country.

Orientation of Education towards noble akhlaq is sometimes overlooked so that the profile that arises from graduates sometimes does not match what is aspired to, (Sanusi, 2016:195), related to this character there are 3 important things to note, namely (1), Regarding each person who appears to be his/her real actions. His actions and his ways of describing some of his personality. (2). The qudrot and irodah factors of God should also not be forgotten in life (3). The basic capital of one's deeds, personality, character and value system is plural intelligence, which is carried genetically and historically, from birth.

Graduates who have noble morals are always raised in the visions of schools including Pesantren, (Sauri, 2006), in philosophy and theosophate Akhlaq says, that: the term character is actually in common with akhlaq. However, if akhlaq is expressly sourced from the Quran and assunnah, then the character is more sourced to the constitution, society and family. Likewise, the value, moral ethics and ethics are actually in fact in relation to akhlaq. And the understanding of value is fithrah tawhidullah developed and internalized in one's person to achieve a noble akhlaq for the happiness of life in this world and in the hereafter.

The formation of akhlaq depends heavily on the environment it faces, "buitstu liutammima makaarimal akhlaq", I was sent to complete akhlaq, showing that the Messenger of God was sent by Allah swt to build / form a human being in order to have a good akhlaq / behavior of creatures to the Kholiq, or in the hadith it is also said, that: "kullu mauluudin yuuladu alal fithrah faabawaahu yuhawwidaanihi au yunashiroonihi au yumazzisaanini, that is, every child is born in a state of fithrah / holy, then both parents will turn them into Jews, Christians, mazusi or remain in the state of fithrah / holy, then both parents will turn them into Jews, Christians, mazusi or remain in the state of fithrahannya.

Management of students in character building can at least go through three domains, namely: 1) affective; the cultivation of character education has an impact on changing attitudes, through habituation that is carried out continuously both in Islamic boarding schools and in schools so that students have certain character traits such as istiqomah, good character, mansiri and others; 2) cognitive: linking character education into subjects provides understanding of students to practice character values and the importance of character in everyday life, so as to stimulate the awareness of students to practice character values in everyday life; and 3) psychomotor: through the learning experiences that students receive both in pesantren and at school, they have abilities that are manifested in the form of behavior in everyday life.

Tahfidz qur'an is a very effective approach in forming noble character because at least when students have the azzam to memorize the qur'an, then at least 5 times a day they will relate to the qur'an as kalamullah, besides that there are several virtues of the qur'an. ; an, namely:

1. Hudan: as a guide for anyone who reads it, understands it and puts it into practice.

2. The Qur'an is referred to as dhikr which is guaranteed authenticity and ease in memorizing it.

3. The contents of the Qur'an are said accurately and clearly, hearing the readings can strengthen and confirm faith.

4. There is a blessing in mixing it, only touched by holy people.

Thus some of these virtues, will only be felt by students who have a target to 
memorize the Qur'an, something that is impossible for those who memorize the Qur'an to only read it once a day, of course at least 5 times a day students will touch the Qur'an in a pure state of soul. and body, so that the emotions, passions that have been in his soul will gradually be clean and replaced with tawadlu and patience in facing the challenges of life. You can imagine that children who used to be very attached to gadgets, from waking up until going to bed were never separated from gadgets, so they indirectly filled their mindset with nutrition that would deliver attitudes and actions in accordance with the content presented by the gadget. , the facts prove that some teenagers / high school are addicted to their tiktok style to the point that before going to bed they can't control their bodies and end up experiencing psychological pain, naudzubillaahi min dzaalik, hopefully our students will be free from such habits.

On the other hand, students who teach themselves to memorize the Qur'an, their days will automatically be filled with memorizing the Qur'an, for example, those who target memorizing 30 juz within 1 year, then they must memorize 1 page a day, repeat the reading / murojaah at least 5 times a day, it is certain that they will not be interested in the jokes contained in the gadget, they will have the view that that time must be used as well as possible and automatically will not engage in wasteful activities that will have no benefit for life and life.

The tahfidz program in Islamic boarding schools or special tahfidz madrasas is one of the efforts to improve the quality of education, especially the formation of noble character, because students are sent to understand the contents of the verses in the Qur'an, reflect on their relationship and position before Allah, they are also accustomed to maintain sunnah practices such as tahajjud, fasting Monday, Thursday, duha prayer, as well as maintaining oral practices and actions that cause memorization to be forgotten or even difficult to memorize. Among the practices that make it easy to memorize the Qur'an are: sincere, serious, patient and confident. The things that will damage the memorization are: immoral acts, lack of murojaah, ujub and riya. So indirectly, students are sent to keep away from actions that are not liked by Allah, even at the same time they save every day for good deeds so that the sanctity of their souls is maintained with the light of the Qur'an. Therefore, the researcher proposes a framework for the development of the PAI curriculum and proposes a study with the title "Management of improving the noble character of students through the Tahfidz approach."

\section{METHOD}

The method the authors used in this study was descriptive analytical method with case studies. Descriptive method of analytics is a research method that emphasizes the effort to obtain information about the status or symptoms at the time of research, provides an overview of the phenomena, also further describes the relationship, as well as draws meaning from a desired problem. (Sukmadinata, 2008) revealed that descriptive research is the most basic form of research and is intended to describe or describe existing phenomena, both natural phenomena and human engineering.

\section{Data Source}

The data sources of this research are boarding school informants in Cimahi City, Bandung City and Garut Regency. The samples taken in this study were students who were taken randomly as many as 10 people, and the Curriculum Team,. Tahfidz educators/tutors are 2 people. Population data, informants were taken based on field observations and data were obtained from the Darul Arqom Muhammadiyah Islamic boarding school in Garut district, and the Misbahunnur Islamic boarding school in Cimahi City.

\section{Data Collection Techniques}

\section{a. Interview}

Through interview techniques, researchers intend to obtain data or information that supports the problem being studied, namely by holding direct conversations with informants as subjects of this study. The form of data collection revealed in this in-depth interview includes the management of fostering the noble character of students with the tahfidz approach in Islamic boarding schools.

b. Observation 
Observation is a systematic and planned observation activity that is intended to obtain data that is controlled for validity and reliability. In this study, the observations made were participatory observation or also called participatory observation, meaning that the researcher observed and participated in the activities carried out by the informants. Observations made directly on the symptoms that appear, as they are in accordance with the (real) reality in the field, the intention is to find out the situation and state of the research subject.

c. Documentation Study

This technique is used with the intention of obtaining administrative data by studying documents related to the problem to be studied, in addition to obtaining complementary data for this research, in order to have credibility. This is in accordance with the opinion Syaodih, NS. (2008:221) that "documentary study is a technique of collecting data by collecting and analyzing documents, both written, graphic and electronic documents".

\section{Data Analysis Techniques}

Data analysis in this study was carried out continuously and continuously, from the beginning to the end of research activities, both in the field and outside the field. Data analysis in the field includes recording, coding, and temporary interpretation of various information obtained at each step of the research activity. The activity steps taken in the analysis of the data are as follows:

a. Data reduction, namely making abstractions of all data obtained from field notes. Data reduction is carried out by researchers, namely by compiling information obtained from informants in the form of narratives related to the focus of research.

b. Organizing and classifying data according to research objectives.

c. Thorough examination of all data to determine completeness and validity, as well as obtain a comprehensive picture of the data, whether it is sufficient or still needs to be added.

d. The interpretation of the data is in accordance with the problem and research objectives, namely compiling and assembling data elements and giving meaning based on the views of the researcher to reach a conclusion in accordance with the research objectives. This is done because essentially all the data in this study support each other and complement each other.

e. Data verification is carried out to check whether the conclusions drawn are correct or not and whether they have achieved the research objectives.

\section{RESULTS AND DISCUSSION}

1. Profile of the Darul Arqom Islamic Boarding School in Garut Regency and the Misbahunnuur Islamic Boarding School in Cimahi City

1) Darul Arqom Islamic Boarding School, Garut Regency

This Islamic boarding school is named Darul Arqam Islamic Boarding School in Garut Region. It is located on Jl. Ciledug No. 284/36 Rt. 01 Rw. 02 Ngamplangsari Village, Cilawu Subdistrict, Garut Regency - 44181 Persyarikatan Muhammadiyah has considerable concerns over the possibility of scarcity of ulama in the future. This concern was raised at the 39th Muhammadiyah congress on 1722 January 1975 in Padang, West Sumatra. Moreover, at that time the Indonesian Minister of Religion, Prof. Dr. H. Mukti Ali, gave a speech at the congress sharply criticizing Muhammadiyah, "Muhammadiyah do not likes to talk and talk about tajdid if Muhammadiyah is not good at speaking Arabic", and also, hopes that Muhammadiyah organizes education that is oriented to the regeneration of scholars.

2) Misbahunnuur Islamic Boarding School The Misbahunnur Foundation as a foundation engaged in social and educational fields has the aim of helping and creating quality human beings both in the world and the hereafter. And this goal is also almost the same and even supports the Cimahi City government program, especially those who want to create a society with personality, noble 
character, intelligent, healthy and superior.

Through the establishment of the Tahfizh Al-Qur'an Islamic Boarding School (PPTQ) Misbahunnur which is the spirit of the Misbahunnur foundation, special management of the planned programs is needed. Therefore, pesantren has a formal education program through the establishment of Madrasah Tsanawiyah (MTs) Misbahunnur and the establishment of Madrasah Aliyah (MA) Misbahunnur. As for non-formal education, pesantren has a program through Madrasah Qur'aniyyah education which requires special management to support the vision and mission of the pesantren, which is to become a leading institution, in this case it is intended to create hafizh and hafizah al-Quran with broad insight.

1. Learning Planning at the Darul Arqom Muhammadiyah Islamic Boarding School, Garut Regency and the Misbahunnuur Islamic Boarding School, Cimahi City.

Based on the results of interviews with pesantren leaders, homeroom teachers and PAI teachers as well as tahfidz supervisors in the two pesantren, namely the Darul Arqom Muhammadiyah Islamic Boarding School in Garut Regency and the Tahfidz Misbahunnur Islamic Boarding School in Cimahi City, it is known that before formulating Islamic religious education plans in order to foster noble character of students in pesantren, the leadership of the pesantren together with the formed team to create a context analysis document. In making context analysis, Islamic boarding schools conduct an analysis of eight national education standards, namely content standard analysis, graduate competency standard analysis, process standard analysis, and management standard analysis. and infrastructure, and financing.

Pesantren also conducts an analysis of the environmental conditions of the education unit, both internal and external environmental analysis. The description of the results of the environmental analysis of the education units in the two pesantren are:

a. External

1) Strength

This analysis of the external environment relates to the strengths of the two pesantren. Among them: 1) Located in the very strategic city center and district. 2) Having adequate teaching staff with academic qualifications in accordance with Law Number 14 of 2005 and Government Regulation Number 74 of 2008.3 ) Having representative educational facilities to carry out Islamic boarding school education.

2) Weaknesses

This analysis of the external environment is related to the weaknesses of the two pesantren. Among them: 1) The environment around the pesantren which tends to be individualistic. 2) There are still teachers who have not been certified as professional educators, especially in the field of tahfidz. 3) Weak cooperation between parents and pesantren in developing more effective learning activities. 4) There are still teachers who teach with conventional approaches and do not understand modern and effective learning models. 5) Library support facilities that have not been maximized. 6 ) The majority of educators are seniors so they are relatively difficult to develop.

b. Internal
1) Opportunity
This analysis of the internal environment is 
related to the opportunities possessed by the two pesantren. Among them: 1) The large number of students has the potential to become the preferred and superior Islamic boarding school. 2) Academic and non-academic achievements of students, especially tahfidz, are many so that they become capital to get support from the community and government. 3) all students are Muslim and have an interest in memorizing the Koran and aspire to be shokleh students so that it is possible to develop Islamic religious education management in order to foster noble character of students through a more effective tahfidz approach.

2) Threat

This analysis of the internal environment is related to the threats that the two pesantren have. Among them 1) The influence of culture outside the pesantren environment that can damage the morale of students, especially gadgets. 2) The lack of educators who hafidz quran from young people so that it threatens the sustainability of the noble character development program for students in the future.

\section{Organizing Learning at the Darul Arqom Muhammadiyah Islamic Boarding School in Garut Regency and the Misbahunnuur Islamic Boarding School in Cimahi City.}

Based on the results of interviews with the leaders of the pesantren, it is known that the planning of Islamic religious education, especially those directed at fostering the noble character of students through the tahfidz approach in both pesantren, is outlined in the pesantren curriculum document. The document was formulated by involving teachers through curriculum revision workshops held at the beginning of each school year. Before being brought into the workshop forum, the curriculum document is formulated by a team formed by the leadership of the pesantren.

As a general guideline for implementers of Islamic religious education in Islamic boarding schools, planning for moral development through the tahfidz approach begins with an affirmation of the vision, mission and objectives of the pesantren as follows:

a. Vision:

1) Darul Arqom Muhammadiyah Islamic Boarding School in Garut Regency To become a model for a national level educational institution with a muhammadiyah character, scientific insight, competitiveness so as to produce a cadre of scholars and/or intellectuals of noble character who drive development, progress and Islam.

2) Tahfidz Misbahunnur Islamic Boarding School in Cimahi City To become the most advanced Islamic boarding school in memorizing, studying, understanding and loving and practicing the Qur'an.

b. Mission:

1) Darul Arqom Muhammadiyah Islamic Boarding School, Garut Regency

a) Organizing the pesantren management system so that it can become a model of excellent educational institutions.

b) Organizing and developing a model of Islamic boarding school education in mastering al ulum aqliyah through the development of an Arabic education/learning model for bahtsul poles and kemuhammadiyahan.

c) Developing Islamic resources that can become superior educational subjects.

d) Establish and develop institutional relationships and cooperation with various related parties as long as they do not conflict with the principles and 
principles of the Muhammadiyah Association.

e) Cultivating students in taste, ratio and sports activities as well as other achievement tests through intra and extracurricular activities.

2) Tahfidz Misbahunnur Islamic Boarding School, Cimahi City

a) Familiarize students to memorize the Qur'an at least one page in one day.

b) Familiarize the students with qur'ani morality in everyday life.

c) Purpose:

1) Darul Arqom Muhammadiyah Islamic Boarding School, Garut Regency

To give birth to tarjih cadres and/or intellectuals who are superior, have noble character who can become cadres of driving development that is more advanced which is Islamic with basic strategies based on togetherness and partnership.

2) Tahfidz Misbahunnur Islamic Boarding School, Cimahi City. Serving religion, homeland and nation to create a society and generation that are strong in faith and science. The expression "Manners in Character" in the vision statement of the pesantren is the main reference for implementing Islamic religious education in pesantren in formulating planning documents that are more operational in order to foster noble character. students through the tahfidz approach.

A vision statement that specifically emphasizes the ideals of forming students who are polite in character or have noble character through the tahfidz approach. According to the leadership of the pesantren, the phrase accustoming students to memorizing the Koran at least one page a day is able to deliver and foster the birth of students with noble character. According to him, noble character is the embodiment of people who have strong faith and carry out the Shari'a well. Akidah, sharia and morals are three aspects that cannot be separated from the structure of Islamic teachings, all of which are the contents of the Koran which students are accustomed to reading, studying and memorizing every day so that people can carry out the appreciation and practice of the Koran effectively. automatically his words, thoughts and deeds are always awake so that he has noble character gradually, both felt and not felt.

Complementing what was conveyed by the leadership of the pesantren, based on the results of interviews with PAI and tahfidz ustadz as well as documentation studies on learning tools for PAI teachers and tahfidz teachers as well as class teacher work programs it is known that in formulating annual programs, semester programs, syllabus and implementation plans for PAI subject learning and tahfidz and other subjects taught by subject teachers, the vision and mission statements become the main guides so that what is planned by PAI teachers, tahfidz teachers and subject teachers is in accordance with the vision and mission of the pesantren that have been previously set, especially those related to the ideals give birth to graduates who are polite in character or noble character.

3. Implementation of Learning at the Darul Arqom Muhammadiyah Islamic Boarding School, Garut Regency and the Misbahunnuur Islamic Boarding School, Cimahi City.

Based on the results of observations and interviews with pesantren leaders, tahfidz teachers, and PAI teachers, it is known that the implementation of Islamic religious education in the two pesantren is carried out through two approaches, namely direct teaching and indirect teaching.

Direct learning is carried out through the delivery of Islamic religious education materials by PAI teachers, character building by subjects, and tahfidz teachers as well as coaching by pesantren leaders in the momentum of Monday's flag 
ceremony and tahfidz session activities. Indirect learning is carried out through the example of the head of the pesantren leadership and all educators, habituation of religious activities with the direction of PAI teachers and tahfidz teachers as well as efforts to create a pesantren culture that is conducive to the formation of noble character of students.

According to the results of interviews with PAI teachers and tahfidz supervisors, it is known that the implementation of Islamic religious education in the context of fostering noble character is also done by getting used to saying greetings when meeting with teachers and entering class, reading prayers every starting and ending learning activities and by reading Asmaul Husna every time. starting the first hour of teaching and learning activities as well as activities that support the achievement of memorization such as daily murojaah, rawaib prayer, tahajjud, duha and shaum sunnah, tasmi and habituation of solemn Friday by reading and understanding Surat al-Kahf, the students will have less opportunities to do things. things that will damage his mind because he is busy with the qur'an.

As for the observations, it is known that in every class, santri room, prayer room and discussion room there are moral messages that inspire and motivate students to behave commendably. In addition to classes, on the walls of the pesantren, the teacher's room and the leadership room of the pesantren, there are also calligraphy and moral messages that are expected to be read every day by students so that they are gradually internalized into the personality system of the students.

Meanwhile, based on the results of interviews with PAI teachers, it is known that pesantren take advantage of the momentum of Islamic holidays as a momentum to instill Islamic moral values, such as the momentum of the Prophet's Birthday, the momentum of the Hijriyah New Year and the Isra Mi'raj Commemoration Moment.

Meanwhile, based on the results of observations throughout the research in both pesantren, it was found that several efforts were developed as the implementation of Islamic religious education in fostering noble character through the tahfidz approach, including the following:

a. Affirming Islamic cultural values in the vision and mission of the pesantren and installed on the wall of the front gate of the pesantren.

b. Installing moral messages in 3 languages, namely English, Arabic and Indonesian, which are posted on every front wall of the classroom, in the classroom, and in the rooms in the Islamic boarding school.

c. Affirming the core character which is the main mission of the pesantren to be transformed into the personality of the santri and installed at the front gate of the pesantren.

d. For subject teachers who teach in the first hour, they are required to guide students to read prayers and Asmaul Husna together.

e. Giving a message to all teachers to always insert Islamic values in their learning practices, without having to expressly these values are listed in the Syllabus and lesson plans.

f. Building the spirit of practicing Islamic teachings through activities for Commemorating Islamic Holidays (PHBI).

g. Install calligraphy in every classroom and other spaces in the boarding school.

h. Involving students in external activities with Islamic nuances.

i. Develop self-development activities, including religious enrichment for santri.

j. Providing rooms and gardens for memorizing and discussing verse studies.

The implementation of Islamic religious education in fostering noble character through the tahfidz approach is reflected in the organizational climate of Islamic boarding schools with an Islamic culture. In general, the climate can be felt from several things as follows:

1) Feels and Looks When Entering the Islamic Boarding School Area

The picket officer who is at the main gate of the boarding school welcomes guests with greetings, 
greetings and courtesy as well as the chanting of the holy Qur'an which is played on a scheduled basis, after passing through the gate guarded by the picket officer, a moral message board contains hadith and verses and pearls of wisdom about virtue memorizing the quran and the culture of shame for the pesantren residents which emphasizes the determination and ideals that the santri want to uphold as well as the profile of the santri that the pesantren aspires to. In front of the entrance, there are pillars of character developed by the boarding school as if it becomes an identity that will be felt by visitors when entering the pesantren environment, on every pillar in the pesantren and in front of the class there are also words of wisdom in English, Arabic and English. Indonesia. What is felt when entering the pesantren area is also the pesantren architecture which is decorated with the vision and mission and goals of the pesantren as well as the profile of the expected graduates.

The polite greeting from the picket officer in front of the boarding gate is also part of the pesantren's cultural identity. This was found by the two pesantren.

2) Looks and Feels When Entering the Boarding Room of the Islamic Boarding School.

The boarding school leadership room is a miniature of the general arrangement of the pesantren environment, the pesantren leadership room is generally equipped with calligraphy, Al-Qur'an manuscripts, the vision and mission of the pesantren, as well as trophies obtained by students in various competitions, especially tahfidz as well as the atmosphere of chanting the holy verses of al-Qur'an. Quran that never ceases to enliven the mood of anyone who enters it.

3) Feels and Feels When Entering the Teacher's Room

Several things that support the implementation of Islamic religious education in order to foster noble character through the tahfidz approach from the arrangement of the teacher's room that the authors find include that the teacher's room is designed with Islamic nuances, including equipped with calligraphy, moral messages in three languages, as well as table and cupboard arrangements that neatly arranged so as to make the residents comfortable in doing their work and make the students interested to conduct consultations and informal discussions regarding teaching materials.

4) Feels and Feels When Entering the Classroom

The classroom becomes a strategic arena for teachers to transform Islamic values and noble character to students. The strategic role of the teacher will be greatly assisted if the class is conditioned in such a way that it supports every stage of learning carried out by the teacher. Some things that can be seen and felt in the classroom include the class equipped with calligraphy, the class equipped with the Qur'an manuscripts, in front and in the classroom equipped with moral message boards in three languages (Indonesian, Arabic and English), there are photographs a photo of the hero of the nation's struggle, there is a vision and mission of the pesantren, there is Asmaul Husna made by students, student rules and promises of students that are installed on the walls.

5) Feels and Feels When Entering the Library Room

The library becomes the scientific identity of an educational institution, through the library, students get many references to enrichment of the basic material received by students from the teacher in class. There are several interesting findings that support the implementation of Islamic religious education in order to foster the noble character of the two pesantren through the library including the library decorated with Islamic wise words in three languages, the library is equipped with Islamic reference books as well as the Qur'anic manuscripts, calligraphy, students are accustomed to saying greetings when entering the library and 
being orderly when registering for borrowing books.

The librarian tries to set an example in morals and gives directions in a polite manner to students who need help, in both pesantren the nuances were felt by the author when conducting research.

6) Feels and Feels When Entering the Canteen

Every break time the majority of students always visit the canteen, so the canteen is a strategic place to be conditioned to support the implementation of Islamic religious education in order to foster noble character in pesantren. There are several findings that support the implementation of Islamic religious education in order to foster noble character through: the tahfidz approach in the canteen, including students getting used to being orderly in taking food, students getting used to storing used food and trash in the places provided by the canteen manager, students getting used to being honest when paying, canteen rooms equipped with Islamic moral messages, students getting used to saying greetings when come and go from the canteen room. And no less interesting, the canteen environment is filled with chanting of the holy verses of the Qur'an so that students' hearing is maintained while helping students in doing murojaah.

7) Environmental Arrangement by Islamic Boarding School.

A well-organized, clean and green environment has a physical and psychological impact on the pesantren residents. In the two pesantren, several things were found related to the arrangement of the pesantren environment, including that the pesantren which was equipped with a pesantren garden became an inspiration and motivation for students to develop learning activities together during breaks, equipped with comfortable benches for discussion and murojaah or even self-memorization in order to ziyadah.
Schools that are equipped with complete facilities and infrastructure also raise students' motivation to learn, Islamic boarding schools become attractive buildings to be used as places to study, neat arrangements provide their own inspiration for pesantren residents to study and work.

Maintenance of environmental cleanliness in the two pesantren is a separate note throughout the study. Pesantren leaders who are concerned with cleanliness aspects give special tasks to pesantren employees to always keep the environment clean, such as ensuring that there is always no scattered garbage, no grass is left long, flowers are always watered and so on. A clean pesantren environment has a psychological impact on visitors and of course on pesantren residents, especially santri to study.

Based on the findings above, it is clear that the physical and psychological atmosphere of the two pesantren supports the implementation of Islamic religious education in fostering noble character, through the tahfidz approach. The arrangement of the pesantren atmosphere is very dependent on the commitment of the pesantren leadership. Pesantren leaders have the authority to direct the work program of the pesantren, including the budget plan and expenditure of the pesantren to matters that support the implementation of Islamic religious education in the context of fostering noble character through the tahfidz approach. If the leadership of the pesantren does not have a view in that direction, the pesantren climate tends to be what it is and runs without a clear direction. In both pesantren, the role of the pesantren committee is very helpful in creating a pesantren climate that supports the implementation of Islamic religious education in order to foster the noble character of students through the tahfidz approach.

4. Assessment/evaluation at the Darul Arqom Muhammadiyah Islamic Boarding School in Garut Regency 


\section{and the Misbahunnuur Islamic Boarding School in Cimahi City.}

a. Assessment of Islamic Religious Education through the tahfidz approach

Based on the results of interviews and observations throughout the study, it is known that the assessment of Islamic religious education in order to foster noble character of students through the tahfidz approach is carried out by the leaders of Islamic boarding schools, PAI teachers and tahfidz supervisors. The assessment process is carried out in writing and some is through the process of experiencing the behavior of students. The results of the assessment are included in the report card and submitted orally through the tahfidz session which was attended by the guardian of the santri in the momentum of the meeting between the class teacher and the guardian of the student at the time of distributing the report card.

Specifically related to programs directed at fostering the noble character of students, Islamic boarding schools set a number of indicators of the success of the Islamic religious education management process in fostering noble character through the tahfidz approach as follows:

a) Be honest during tests and exams, ziyadah/memorization deposits

b) Doing daily morojaah

c) Doing the practice of supporting memorization

d) Leaving practices that damage memorization

e) Istiqomah in memorizing and murojaah and ziyadah

f) Honest and brave and confident when doing tasmi and siding

g) Say hello every time you meet teachers, other students and school guests.

h) Using polite language

i) Caring about the cleanliness of the environment

j) Dress neatly in accordance with school rules

k) Come and go home on time

l) Pray every time you start Teaching and Learning Activities (KBM)

$\mathrm{m}$ ) Visit each other if someone is sick n) Apologize when guilty

o) Be grateful when something is given

p) Be grateful when you get an achievement/award

q) Not involved in brawls, drugs, free sex and other symptoms of social pathology.

Improvement of Islamic Religious Education

b. Improvement of Islamic Religious Education

Based on the results of interviews and observations throughout the study, it is known that the improvement of Islamic religious education in fostering the noble character of students through the tahfidz approach is carried out by the pesantren leaders, PAI teachers and tahfidz supervisors. Repairs are carried out with the following objectives:

1) Give special treatment to students in the two pesantren who experience obstacles in the memorization activities programmed by the pesantren.

2) Provide assistance to students in the two Islamic boarding schools who experience difficulties or learning delays.

3) Providing optimal services through remedial learning processes so that the principle of complete learning is achieved.

The main problem that will always arise in the implementation of complete learning is "how the teacher handles students who are slow or have difficulty in mastering certain basic competencies". There are two ways that can be taken, namely:

a. Providing special and individual guidance for students who have not or have difficulty in memorizing certain verses or letters by providing memorization techniques and motivating their souls to focus. This way is an easy and simple way to do it because it is an implication of the role of a mentor as a friend of the Quran.

b. Giving tasks or treatment (treatment) specifically, which is a simplification of the implementation of regular learning pembelajaran. 
c. The form of simplification can be done by the teacher, among others, through:

d. Simplification of learning strategies for certain KD.

e. Simplification of the way of presentation (for example: using pictures, models, schematics, graphs, providing simple summaries, etc.)

f. Simplification of questions/questions given.

The improvement process is carried out in writing and some is through a process of strengthening the behavior of students. The results of the improvements are included in the report card document and delivered orally in the momentum of the meeting between the class teacher and the guardian of the students at the time of distributing report cards and the tahfidz session.

Based on the above, then (Megawangi, 2004) said that schools are strategic places for character education, because children from all walks of life will receive education in schools. In addition, children spend most of their time in school, so what they get at school will affect the formation of their character. The Government Regulation (PP) No. 19 of 2005 Paragraph 2 and Paragraph 3 as has been refined by PP No. 32 of 2013 explains the National Education Standards (SNP) that must be met by schools to carry out their roles to the fullest, including their role in shaping the character of students so that can give birth to students who have noble rights.

SNP is the minimum criteria regarding the education system in all jurisdictions of the Unitary State of the Republic of Indonesia. As explained in the results of the research above, before formulating Islamic religious education plans in fostering the noble character of students through the tahfidz approach in pesantren, the pesantren leadership made a mapping of the objective conditions of the pesantren related to the eight SNPs documented in context analysis. This is a very important activity in order to measure strength the true nature of the pesantren and the aspects that are considered weak from the pesantren. In other terms, it is an effort to selfevaluate the pesantren.

However, the results of the context analysis should be followed up by the pesantren leadership by immediately fixing the standards that are considered weak and strengthening the standards that are considered close to the SNP provisions. So that the implementation of any planning made by the pesantren can be carried out properly.

The pesantren's commitment to fostering noble character through the tahfidz approach begins with an affirmation of the vision, mission and goals of the pesantren. This is very important in relation to the vision, mission and goals that illustrate that the pesantren has a clear direction for each program it undertakes. In addition, the vision, mission and goals will also serve as a common guide for all parties in the pesantren in determining strategic steps according to their respective roles.

The expression of the pesantren's vision which explicitly confirms the ideals of giving birth to graduates who are "hafidzoh and polite in character" becomes the main reference for implementing Islamic religious education in pesantren in formulating more operational planning documents in order to foster noble character of students through the tahfidz approach. Based on the document, the vision, mission and goals of the two pesantren have coherence, where the ideals of producing graduates who have noble character are gradually emphasized, both in the vision, mission and goals of the pesantren and even up to teacher learning tools. This indicates that from the strategic planning aspect, the two pesantren already have a strong foundation and basic commitment.

At the implementation level, Islamic religious education in the two pesantren is carried out through two approaches, namely direct teaching 
and indirect teaching. Specifically related to direct learning, it is carried out through the delivery of Islamic religious education materials by PAI teachers, as well as tahfidz mentors, character development by santri guardians, and coaching by Islamic boarding school leaders in the momentum of the solemn Monday and Friday flag ceremony The two boarding schools need to develop other models as suggested by (Majid, Wardan, \& Andayani, 2011) that in character education towards the formation of noble character of students, there are three stages of strategies that must be passed, namely moral knowing (learning to know), moral loving (moral feeling), and moral doing (learning to do). Other than that, (Majid et al., 2011) also provides three alternative models that can be used in implementing the development of noble character of students in schools. The models are as follows:

1) Tadzkirah Model

2) Istiqomah Model

3) Iqra-Fikir-Dhikr Model Moreover, (Aunillah, 2011) provides a recommendation that in fostering character, including the noble character of students, teachers can use a contemporary method known as the lesson study method. In Japanese, the method is called Jugyogkenkyu which means a form of activity carried out by a teacher or a group of teachers in collaboration with other people. This method provides broad opportunities for teachers to be able to witness the real learning process (teaching) and learning or student learning (leaning) in the classroom. Thus, the leasen study method is a method that can guide teachers to focus discussions on planning, observing or observing, and reflecting on learning practices in class.

Other models such as habituation of positive behavior in schools that are guided by teachers and homeroom teachers as done in the two pesantren are very good to be developed. Conditioning the physical environment that supports efforts to foster noble character for students is also an important part that must be developed. So that a pesantren culture is formed that is conducive to efforts to realize the vision of fostering noble character in pesantren.

In measuring the effectiveness of the use of models, approaches and methods carried out by Islamic boarding schools, of course there needs to be an assessment effort so that the level of achievement and success can be measured and improvements can be made if weaknesses are found. In measuring the effectiveness of using a model, approach and method, of course, it is necessary to first determine a number of indicators of success and a minimum standard of success.

A number of indicators set by the two pesantren are good enough to measure the success of fostering noble character through the tahfidz approach carried out by pesantren. However, these indicators should be developed based on three goals of moral development, namely knowing, feeling and acting in an integrated manner. In conducting the assessment, it seems that pesantren have not done it in a balanced manner, the knowing or cognitive aspect is still the prima donna in assessing the level of success of the coaching program carried out.

The implementation of Islamic religious education management in order to foster noble character is influenced by many components. In the context of education management, there are at least 10 educational components that influence efforts to develop Islamic religious education, namely: 1 . Educational Goals, 2. School Vision and Mission, 3. Content/material/curriculum, 4. Environmental Situation, 5. Educational Tools / Educational Facilities and Infrastructure, 6. Students 7. Educators / Teachers, 8. Principals. 9. School Committee. 10. Extracurricular Coach.

1. Components of Educational Goals

The purpose of education serves as the direction to be directed in educational activities. With a clear goal, the other 
components of education and their activities are always guided by the goal, so that the effectiveness of the educational process is always measured whether it can and in order to achieve the goal or not.

In the context of national education, it is clear that the purpose of education as affirmed in Law No. 20 of 2003 chapter II Article 3 that national education functions to develop capabilities and shape the character and civilization of a dignified nation in the context of educating the nation's life aims to develop the potential of students to become human. who believe and fear God Almighty, have noble character, are healthy, knowledgeable, capable, creative, independent and become democratic and responsible citizens.

The existence of words of faith and piety to God Almighty, noble character, healthy, knowledgeable, capable, creative, independent and being a democratic and responsible citizen in the goals of national education above indicates that the teaching materials and educational evaluation process are not only cognitive aspects, but affective and psychomotor.

As for (Mulyana, 2004) argues that the main goal of national education emphasizes aspects of faith and piety. This implies that the core value of building the nation's moral character comes from religious beliefs. That is, all educational processes must lead to strengthening divine values in accordance with the religious beliefs they believe in.

2. School Vision and Mission

A quality school, of course, must have a clear, measurable and realistic vision and mission. From the vision and mission presented, it can be seen how the goal orientation and output profile will be generated. This vision and mission statement can be taken from several aspects, including religious, academic, mental, behavioral, life skills, independence

and

entrepreneurship aspects.

3. Education Curriculum Components

The curriculum is one of the tools to foster and develop students to become human beings who believe and fear God Almighty, have noble character, are healthy, knowledgeable, capable, creative, independent, and become democratic and responsible citizens.

4. Components of the Educational Environment

The educational environment is a space and time that supports educational activities. The educational process is in an environment, be it a family environment, school environment or community environment. Students with various potentials will develop optimally if they are in a conducive environment. In accordance with the opinion of A. Noerhadi Djamal $(1995: 27)$ that the environment has a major and decisive influence on the continuity of the development of students' self-potential.

According to (Nata, 2010) that in general, and Islamic education in particular, there is an agreement that the educational environment consists of the family environment, school environment and community environment.

As for (Mulyasa, 2004) that a conducive environment, among others, can be developed through various services and activities as follows.

a. Provide options for students who are slow or fast in carrying out learning tasks. Individual choices and services for students, especially for those who are slow learners, will arouse their passion and enthusiasm for learning, thus making them feel at home studying at school.

b. Provide remedial lessons for students who lack achievement, or low achievers. In the classical learning system, some students will find it difficult to follow the learning optimally, and demand 
an extra role from the teacher to provide remedial learning.

c. Develop an effective, attractive, comfortable, and safe class organization for the optimal development of the potential of all students. Included in this is the provision of interesting and challenging learning materials for students, as well as appropriate, effective, and efficient classroom management.

d. Creating mutual respect cooperation, both between students and between students and teachers and other learning managers. This implies that every student has the widest opportunity to express his views, there seems to be a fear of getting sanctioned or humiliated..

e. Involve students in the learning and learning planning process. In this case, the teacher must be able to position himself as a guide and human resource. Once in a while, try to involve students in the learning planning process, so that they feel responsible for the learning carried out.

f. Developing the learning process as a shared responsibility between students and teachers, so that teachers act more as facilitators, and as learning resources.

g. Develop a learning and learning evaluation system that emphasizes self-evaluation. In this case, the teacher as a facilitator must be able to help students to assess how do they make progress in the learning process they go through?.

\section{Educational Tool}

Educational tools are supporting and supporting the implementation of education that serves as an intermediary when delivering educational materials by educators to students in achieving educational goals. Educational events are characterized by educational interactions. In order for the interaction to take place effectively and efficiently in achieving goals, in addition to selecting the right educational material, it is necessary to choose the right method and media as well. A method is a way in which its function is a tool to achieve a goal. To determine whether a method can be called appropriate or not, criteria are needed that are based on several factors. The main determining factor is the goal to be achieved.

Project method, solving problems with scientific, logical, and systematic steps.

Al-Ghazali in (Armai, 2002) suggested several alternative methods used in educating, namely as follows:

a) Mujahadah and Riyadlah Nafsiyah (strength and mental training), namely educating children by repeating experiences. This leaves a good impression on the souls of students and will really pursue it so that morals and character are formed in him.

b) Educating children should use several methods. The use of various methods will generate motivation to learn and eliminate boredom.

c) Educators should provide encouragement and punishment. Ibnu Khaldun in (Armai, 2002) argues that educational methods that can be an alternative are as follows:

1. The modern scientific method, which is to cultivate the ability to understand science with fluency in speaking in discussions to avoid verbalism in lessons.

2. The method of grading (phasing) and repetition. Knowledge is global, gradual and detailed so that children understand problems and receive explanations according to their level of thinking. 
3. Using media (props) to help students understand the subject matter.

4. Conduct field trips so that students get hands-on learning experiences.

5. Avoid the system of teaching material in the form of an overview (summary).

6. Provide proportional sanctions to foster student learning motivation (spirit).

In terms of choosing the right method, a teacher needs to pay attention to the principles of implementing the educational methodology according to AlSaibany in (Armai, 2002) namely as follows;

1) Knowing the motivation, interests, and needs of their students.

2) Knowing education.

3) Knowing the stages of maturity, development, and changes in students.

4) Knowing individual differences in students.

5) Pay attention to understanding and knowing relationships, integration of experience and continuation, originality, renewal, and freedom of thought.

6) Make the educational process an enjoyable experience for students.

7) Uphold "uswah hasanah".

\section{Student Component}

In the context of this research, students have a strategic role in the development of Islamic cultured schools, students can be played as objects as well as subjects of development. School rules, dormitory rules and student appointments can be instruments so that students are fully involved in the development of Islamic-cultured schools.

\section{Educator/Teacher Component}

The teacher for students is a spiritual sage who feeds himself with knowledge, the teacher is a person who glorifies the morals of his students. The teacher is a person full of love for his children (students). The life and death of learning depends on the teacher. Teachers are the powerhouses of future students' lives. This is where the role and function of the teacher is so noble whose position is equal to Allah's Apostle who was sent to a people (Barizi \& Idris, 2009).

\section{Principal Component}

The principal has a strategic role in the development of Islamic religious education in order to foster the noble character of students, because in the context of schoolbased management, a principal has more authority in determining the direction of the development of the school he leads. In the perspective of national education policy (Kurikulum, Depdiknas, \& No, 2006) as developed by Daryanto (2009:30-34) that there are seven main roles of the principal which are expected to optimize the role and function of the school as an institution that produces quality and competitive human resources. The seven roles are 1) to schools as educators, 2) to schools as managers, 3) to schools as administrators, 4) to schools as supervisors, 5) to schools as leaders, 6) to schools as creator of the work climate, 7) to schools as entrepreneurs. Daryanto added the role of the principal in guidance and counseling services.

9. School Committee Components

The school committee has the obligation to support and participate in applying the duties of school principals and teachers to develop Islamic religious education in order to foster students' noble character and communicate to parents to create a conducive atmosphere so that the development of Islamic religious education in order to foster students' noble character goes well.

According to (Mulyasa, 2004) In implementing character education, the School/Madrasah Committee acts as: 
a) Advisory agency in determining the implementation of character education policies in schools/madrasahs;

b) Supporting agencies, both in the form of finance, thoughts, and personnel in the implementation of character education;

c) Controlling (controlling agency) in the context of transparency and accountability in the implementation and output of the quality of character education;

d) Intergovernmental mediator (executive) with the community, and schools/madrasahs, in the implementation of character education.

e) In the implementation of Islamic religious education as an effort to foster students' noble character, the Madrasah Committee functions as follows.

f) Encouraging the growth of public attention and commitment to the implementation of Islamic religious education in the context of fostering the noble character of quality students.

g) Cooperating with the community (individuals/organizations/busine ss/industrial world) and the government regarding the implementation of Islamic religious education in the context of fostering the noble character of students.

h) Accommodate and analyze aspirations, ideas, demands, and various needs of Islamic religious education in the context of fostering the noble character of students proposed by the community.

i) Provide input, considerations and recommendations to schools/madrasahs regarding character education policies and programs; character education performance criteria; educational staff criteria; criteria for character education facilities; and matters related to Islamic religious education in the context of fostering the noble character of students in schools/madrasas.

j) Encouraging parents and the community to participate in Islamic religious education in order to foster students' noble character in order to support quality improvement and implementation.

k) Raising public funds in financing the implementation of Islamic religious education in the context of fostering the noble character of students.

I) Evaluating and supervising policies, programs, implementation, and nobility of Islamic religious education in the context of fostering the noble character of students.

\section{Extracurricular Coaching \\ Component}

According to (Nata, 2010) that the strategic steps of religious education in the context of fostering students' morals or character include the following:

First, moral education can be done by strengthening the implementation of religious education, because religious values and teachings are ultimately aimed at forming good morals.

Second, religious education
that can produce moral improvement must be changed from a religious teaching model to religious education.

Third, moral education can be carried out with an integrated approach, namely by involving all scientific disciplines.

Fourth, in line with the third method mentioned above, moral education must involve all teachers. Moral education is not only the responsibility of religious teachers as has been emphasized, but the responsibility of all teachers.

Fifth, moral education must be supported by the will, solid cooperation and genuine effort from the family/household, school, 
and community. Parents at home should increase their attention to their children, by taking the time to provide good guidance, role models, and habits.

Sixth, moral education must use all opportunities, various means including modern technology. Creative opportunities, exhibitions, excursions, camping, and so on should be used as opportunities to build morale. Likewise, various facilities such as mosques, prayer rooms, educational institutions, newspapers, magazines, radio, television, internet and so on can be used to foster morale.

Furthermore (Nata, 2010) revealed that what is meant by the morals of students is not just things related to words, attitudes, and actions that must be added by students in socializing at school and outside of school, but various other provisions that enable the effectiveness of the teaching and learning process Knowledge of the morals of these students not only needs to be known by every student with the aim of applying it, but also needs to be known by every educator, with the aim of being able to direct and guide students to follow these morals.

\section{CONCLUSION}

The West Java Provincial Government and the Garut Regency Government should synergize with Islamic boarding schools to create a management model of Islamic religious education in fostering students' noble character that is more effective and measurable. In addition, the government needs to pay attention to the feasibility of the eight National Education Standards (SNP) owned by schools as internal support for the process of quality Islamic religious education. School managers must also carry out selfevaluations on an ongoing basis and report them to the Regional Government so that any existing deficiencies can be continuously improved.

The Education Office should make a tahfidz curriculum for schools or madrasas as an effort to minimize the moral decadence that is being faced by early childhood children and adolescents especially with the enormity of more interesting information presented by gadget media so that with the tahfidz curriculum schools from elementary to secondary levels are able to make a medium for fostering the noble character of students.

\section{REFERENCES}

Armai, Arief. (2002). Pengantar Ilmu Dan Metodologi Pembelajaran Agama Islam. Jakarta: Ciputan Press.Google Scholer

Aunillah, Nurla Isna. (2011). Panduan menerapkan pendidikan karakter di sekolah. Yogyakarta: Laksana, 80. Google Scholer

Barizi, Ahmad, \& Idris, Muhammad. (2009). Menjadi guru unggul. Yogyakarta: ArRuzz Media. Google Scholer

Kurikulum, Pusat, Depdiknas, Balitbang, \& No, Jl Gunung Sahari Raya. (2006). Pengembangan Model Pendidikan Kecakapan Hidup. Jakarta Pusat. Google Scholer

Majid, Abdul, Wardan, Anang Solihin, \& Andayani, Dian. (2011). Pendidikan karakter perspektif Islam. PT Remaja Rosdakarya. Google Scholer

Megawangi, Ratna. (2004). Pendidikan karakter. Jakarta: Indonesia Heritage Fondation. Google Scholer

Mulyana, Rohmat. (2004). Mengartikulasikan pendidikan nilai. alfabeta. Google Scholer

Mulyasa, Enco. (2004). Manajemen berbasis sekolah: konsep, strategi dan implementasi. Google Scholer

Nata, H. Abuddin. (2010). Integrasi ilmu agama \& ilmu umum. Rajagrafindo Persada. Google Scholer

Sauri, H. Sofyan. (2006). Pendidikan Berbahasa Santun. PT Genesindo. Google Scholer 
Sukmadinata, Nana Syaodih. (2008). Metode

Penelitian Kualitatif Pendidikan.

Bandung: PT Rosdakarya. Google

Scholer

\section{Copyright holder:}

Rohaeti, Ulfiah, Daeng Arifin, Ahmad Khori (2021)

First publication right:

Journal of Social Science

This article is licensed under:

(cc) (i) (?) 